doi: 10.32620/oikit.2021.92.07

УДК 621.835

Е. Фролов ${ }^{1}$, Б. Коробко ${ }^{1}$, С. Ясько ${ }^{1}$, В. Агарков ${ }^{2}$

\title{
Зниження металомісткості ротаційно-профільованих колісних ободів різних типів і товщини
}

\author{
${ }^{1}$ Національний університет «Полтавська політехніка \\ імені Юрія Кондратюка» \\ ${ }^{2}$ Державне підприємство «Харківстандартметрологія»
}

\begin{abstract}
Проведені дослідження дозволили розробити нову схему процесу ротаційного профрілювання колісних ободів, яка дозволяє знизити металомісткість деталей. Суть рішення полягає в тому, що на другому переході передбачено примусовий підпір центральної частини струменя. Це дозволяє змінити характер деформації після другого переходу і усунути непотрібне потовщення основи струменя. Зі збільшенням глибини струменя крайові ділянки піддаються незначним розтягувальним напруженням, при цьому напружено-деформований стан деталі залишається симетричним і постійним у кожній точці. Відпрацьована послідовність розрахунку нового технологічного процесу, що дозволяє розрахувати всі технологічні параметри: визначається ширина і довжина плоскої заготовки; визначається найбільша допустима величина напружень у матеріалі заготовки; визначається маршрут профілювання; виявляються деформації і напруження для крайових елементів і на небезпечних ділянках; далі 3 урахуванням пружних деформацій заготовки будується профіль роликів, а потім розраховується оптимальне зусилля деформування по переходах, призначаються подача і кількість обертів роликів. Нова схема дозволила знизити металомісткість деталей і отримати суттєвий економічний ефект. Виключається овальність деталі і багаторазова повторна деформація одних і тих самих ділянок оброблюваної деталі, а також знижується ступінь зміцнення матеріалу.

Ключові слова: ротаційна обробка, параметри, якість, обід, колесо, лист.
\end{abstract}

\section{Вступ}

Процеси ротаційного оброблення металів тиском дозволяють обробляти високоміцні й низькопластичні матеріали, отримуючи вироби різної конфрігурації на обладнанні невеликої потужності при малих затратах на технологічне оснащення, наприклад ободи коліс різних автомобілів, тракторів та інших типів транспортних засобів).

Важливим завданням $€$ не тільки забезпечення високої якості виробів, а й зниження металомісткості профрільованих деталей.

Як показала практика, відомі технологічні схеми, що включають радіальне профрілювання [1 - 6], знижують експлуатаційні якості деталей унаслідок значного стоншування стінок (рис. 1).

Стоншування, наприклад для таких масових деталей, як обіддя коліс різних транспортних засобів, становлять $16 \ldots 25,5$ \%. У таких випадках застосовують заготовки із завищеною товщиною, що збільшує металомісткість ість виробів.

Метою досліджень $€$ розроблення нової схеми профрілювання, яка дозволить знизити металомісткість деталей і отримати суттєвий економічний ефрект, а також зменшити ступінь зміцнення обробленого матеріалу заготовок колісних ободів. 


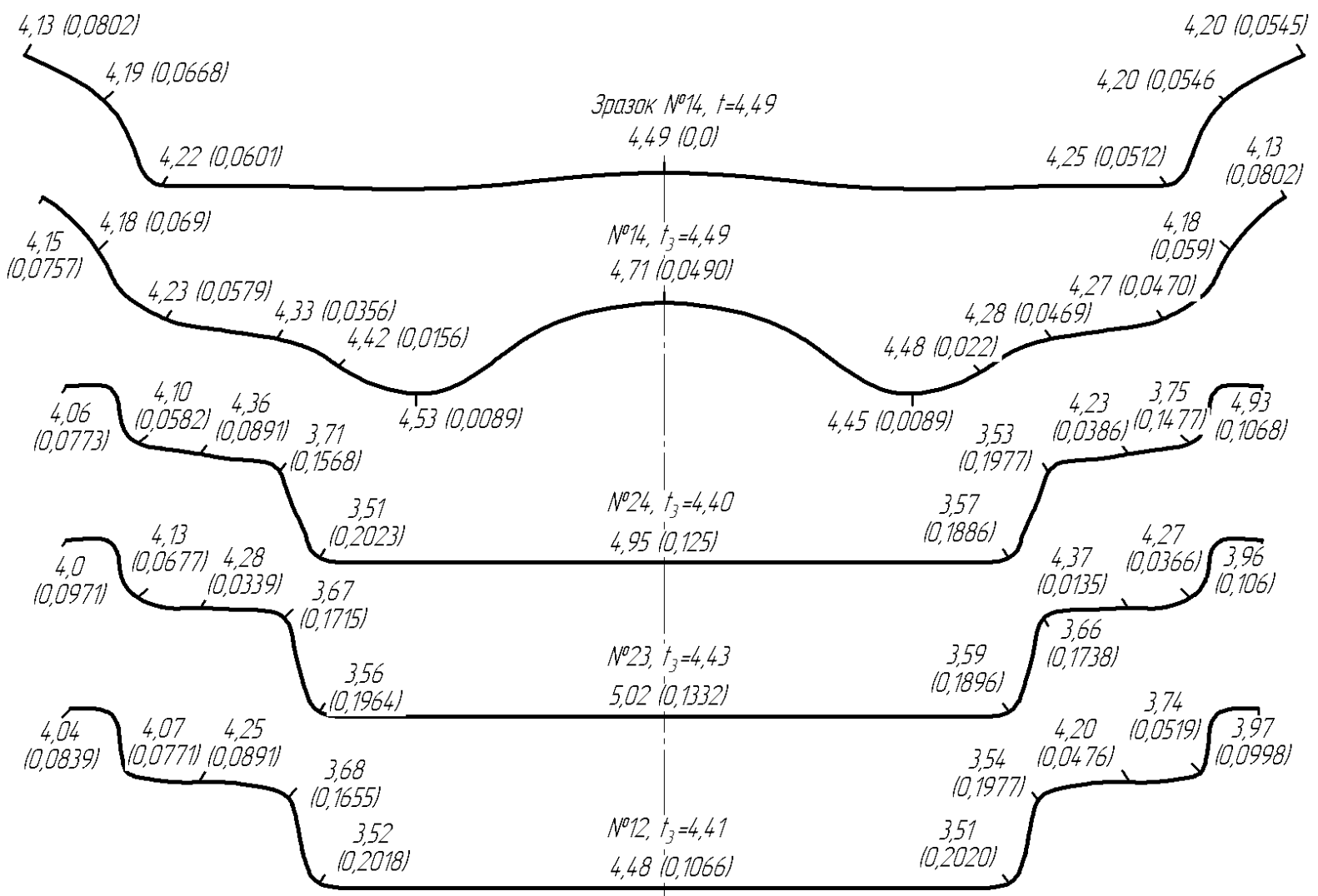

Рис. 1. Профрілограми для обода W8-16, змінення товщини та потоншення (у дужках) стінки при профілювання без підпору за діючою технологією

( $\mathrm{t}$ - товщина вихідної заготовки)

Локалізація осередку деформації суттєво зменшує зусилля деформування, що дозволяє оброблювати високоміцні й низькопластичні матеріали та отримувати вироби різноманітної конфрігурації на обладнанні 3 порівняно невеликою потужністю, наприклад ободи коліс різних транспортних машин (автомобілів, легких літальних апаратів тощо).

\section{Основний матеріал}

Проведені додаткові лабораторні дослідження дозволили розробити нову схему процесу профрілювання, позбавлену зазначених недоліків.

Профрілювання виконується у три переходи (рис. 2). На другому переході передбачається примусовий підпір у центральній частині струменя.

Меридіональні (уздовж твірної профрілю) $\varepsilon_{m}$ і тангенціальні $\varepsilon_{\theta}$ деформації (табл. 1) та інтенсивності $\varepsilon_{i}$ розраховано за зміненнями розмірів ділильної сітки, тангенціальні $\varepsilon_{\theta}^{\prime}$, радіальні (за товщиною) $\varepsilon_{r}^{\prime}$ деформації та інтенсивності $\varepsilon_{i}^{\prime}-$ за зміненнями діаметра і товщини стінки заготовки або напівфабрикату. При розрахунку деформацій для зразків 1-, 2- і 4-ї груп як початкові вибирали розміри обичайки, для зразків 3-ї групи - розміри напівфабрикату першого переходу.

Найбільшої напруженості на першому переході зазнають ділянки (див. рис. 2) з точками 05, на другому - з точками 04 і на третьому - 3 точками 01.3 певним припущенням можна вважати, що кожен елемент профілю деформується один раз. 
Зони стиснуто-розтягнутих елементів розташовуються на ділянках 3 точками 03, 04, 01 і 02. Тут у меридіональному напрямку відбувається згинання з подовженням волокон на опуклих поверхнях і з укороченням - на увігнутих, що сприймають тиск з боку роликів. У зонах 05, 06, 07 на першому переході волокна подовжуються по всьому перерізу, що знижує локальні деформації в радіусних переходах.

Тангенціальні деформації негативні на першому і позитивні на третьому переході. У зоні стиснення за абсолютною величиною (перехід перший, точка 07) вони більше, ніж у зоні розтягування (перехід третій, точка 01). Ця різниця дещо скорочується після другого переходу завдяки підпору у центральній частині струменя. Характер змінення деформацій відповідає збільшенню діаметра кільцевої ділянки з точками 03 на першому і другому переходах унаслідок пружної післядії.

Додаткові зони стоншування (перший перехід, точки 05) усувають непотрібне потовщення основи струменя. Деформації $\varepsilon_{r}^{\prime}$ негативні в усіх характерних перерізах. Наростаючі дефрормації, розраховані для зразків третьої групи, розподілені найбільш сприятливо і спричиняють невисоку інтенсивність $\varepsilon_{i}$.

Характер змінення товщини стінки напівфрабрикатів і стоншування показано на рис. 3.

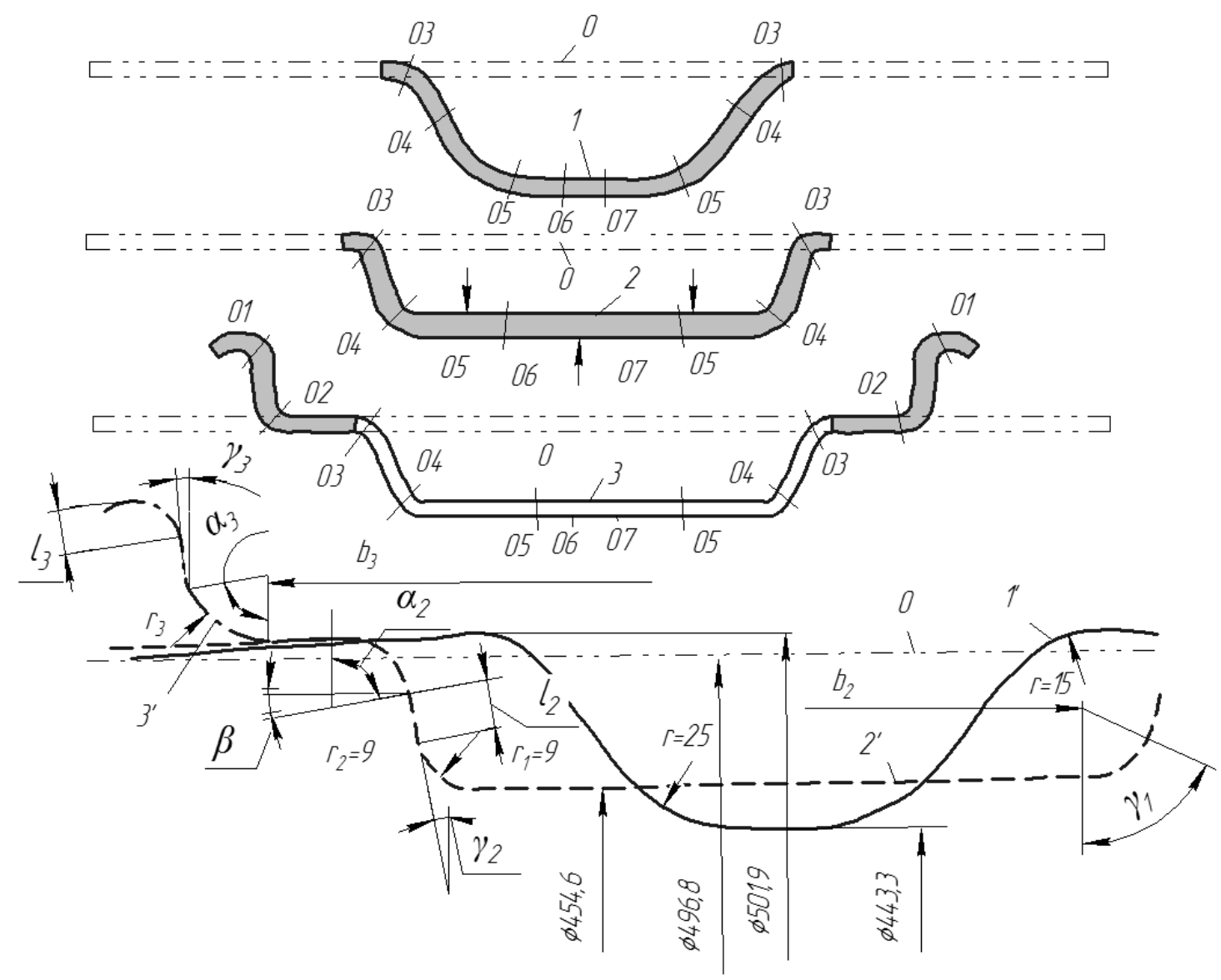

Рис. 2. Схема нового технологічного процесу: 1', 2', 3' - напівфрабрикат першого, другого, третього переходів під навантаженням; 0 - профіль обичайки 
Таблиця 1

Результати вимірювань

\begin{tabular}{|c|c|c|c|c|c|c|c|c|}
\hline \multirow{2}{*}{ 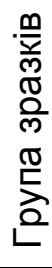 } & \multirow{2}{*}{$\begin{array}{l}\frac{\mathfrak{d}}{x} \\
\stackrel{0}{d} \\
\frac{0}{0}\end{array}$} & \multirow{2}{*}{$\begin{array}{l}\text { * } \\
\text { 뚯 } \\
\text { Х } \\
0 \\
0 \\
0 \\
0 \\
0 \\
\text { 은 }\end{array}$} & \multirow{2}{*}{ 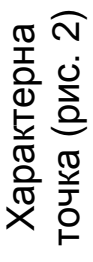 } & \multicolumn{5}{|c|}{$\begin{array}{c}\text { Поточні та сумарні деформації, що зростають, та інтенсивності } \\
\text { дефрормацій ** }\end{array}$} \\
\hline & & & & $\varepsilon_{m}$ & $\varepsilon_{\theta}$ & $\varepsilon_{\theta}^{\prime}$ & $\varepsilon_{r}^{\prime}$ & $\varepsilon_{i}\left(\varepsilon_{i}^{\prime}\right)$ \\
\hline 1 & 2 & 3 & 4 & 5 & 6 & 7 & 8 & 9 \\
\hline \multirow{6}{*}{1} & \multirow{6}{*}{1} & 3 & 03 & $0,16(0,13)$ & $-0,005$ & $0,01(0,02)$ & $-0,05$ & $\begin{array}{c}0,28(0,23 \\
)\end{array}$ \\
\hline & & B & 03 & $-0,105$ & $-0,03(-0,02)$ & $0,01(0,015)$ & $-0,05$ & 0,20 \\
\hline & & 3 & 05 & $0,19(0,15)$ & $-0,19(-0,18)$ & $-0,14(-0,11)$ & $-0,10$ & $\begin{array}{c}0,32(0,28 \\
)\end{array}$ \\
\hline & & B & 05 & $0,23(0,26)$ & $-0,14(-0,12)$ & $-0,13(-0,11)$ & $-0,10(-0,09)$ & $\begin{array}{c}0,37(0,44 \\
)\end{array}$ \\
\hline & & 3 & 07 & 0,15 & $-0,20$ & $-0,16$ & $-0,04$ & 0,27 \\
\hline & & B & 07 & 0,15 & $-0,15$ & $-0,14$ & $-0,04$ & 0,26 \\
\hline \multirow{6}{*}{2} & \multirow{6}{*}{2} & 3 & 03 & $0,165(0,15)$ & $-0,008$ & 0,005 & $-0,04(-0,035)$ & 0,26 \\
\hline & & B & 03 & $-0,19$ & $-0,05(-0,03)$ & $-0,005$ & $-0,045$ & 0,36 \\
\hline & & 3 & 04 & $-0,08$ & $-0,18$ & $-0,12$ & $-0,08$ & 0,37 \\
\hline & & B & 04 & 0,30 & $-0,09(-0,08)$ & $-0,11$ & $-0,08$ & 0,46 \\
\hline & & 3 & 06 & 0,15 & $-0,165$ & $-0,12$ & $-0,035$ & 0,32 \\
\hline & & B & 06 & 0,12 & $-0,14$ & $-0,12$ & $-0,035$ & 0,27 \\
\hline \multirow{6}{*}{3} & \multirow{6}{*}{2} & 3 & 03 & $0,08(0,13)$ & $-0,005$ & $-0,01(-0,005)$ & $-0,015(-0,02)$ & $(0,23)$ \\
\hline & & B & 03 & $-0,12(-0,18)$ & $-0,02$ & $-0,015(-0,01)$ & $0,02(0,04)$ & $(0,30)$ \\
\hline & & 3 & 04 & $-0,13(-0,08)$ & $-0,125(-0,135)$ & $-0,04(-0,065)$ & $-0,09$ & $(0,34)$ \\
\hline & & B & 04 & 0,30 & $-0,06(-0,05)$ & $-0,04(-0,065)$ & $-0,09$ & $(0,48)$ \\
\hline & & 3 & 06 & 0,005 & 0,01 & 0,01 & $-0,01$ & $(0,08)$ \\
\hline & & B & 06 & $-0,08$ & 0,02 & 0,01 & $-0,01$ & $(0,10)$ \\
\hline \multirow{4}{*}{4} & \multirow{4}{*}{3} & 3 & 01 & 0,24 & 0,11 & 0,105 & $-0,10$ & 0,52 \\
\hline & & B & 01 & $-0,16$ & 0,10 & 0,095 & $-0,10$ & 0,50 \\
\hline & & 3 & 02 & $-0,17$ & 0,005 & 0,008 & $-0,05$ & 0,18 \\
\hline & & B & 02 & 0,33 & 0,008 & 0,009 & $-0,08$ & 0,25 \\
\hline
\end{tabular}

* Поверхня 3 - зовнішня і В - внутрішня.

** У дужках наведено величини для однойменних точок профрілю.

Зі збільшенням глибини струменя крайові ділянки піддаються значним напруженням розтягнення. Напруження розглянуто у кінцевому моменті, коли напружено-деформований стан залишається симетричним і постійним у кожній 
точці, які рівновіддалені від осі обертання напівфабрикату і лежать у площині даного поперечного перерізу.

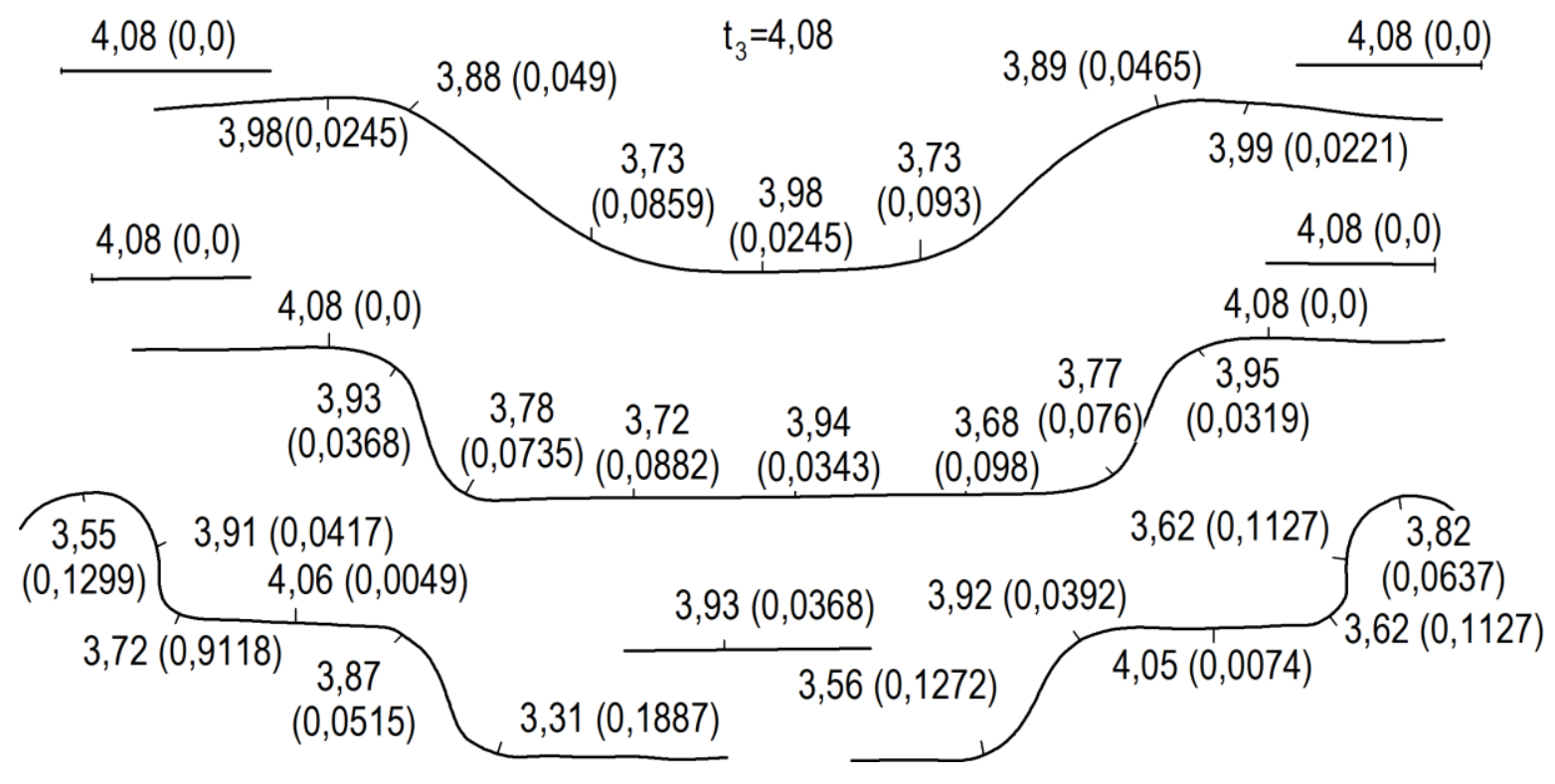

Рис. 3. Профрілограми для ободів W 8-16, змінення товщини і потоншення (у дужках) стінки при профрілюванні з підпором за розробленою схемою

3 умови рівноваги елементарної ділянки (рис. 4) були складені відповідні рівняння. Розв'язання їх сумісно з умовою пластичності і рівнянням прямої дозволило отримати формули для розрахунку і аналізу меридіональних $\sigma_{m}$ i тангенціальних $\sigma_{\theta}$ напружень і питомих зусиль $q$ деформування:

$$
\begin{gathered}
\sigma_{m}=\frac{\varphi \cdot \sigma_{\theta} \cdot \cos \varphi}{\cos ^{2} \alpha}\left(1-\frac{y_{c p}}{R_{c p}}\right)+\frac{q(1-\mu \cdot \operatorname{ctg} \alpha)}{t_{i} \cdot \cos \alpha} y_{c p}^{2}\left(1-\frac{R_{c p}}{y_{c p}}\right) ; \\
\sigma_{\theta}=\beta \sigma_{s} \frac{\varphi(b+x \cdot \operatorname{tg} \alpha) \cos \alpha}{\varphi(b+x \cdot \operatorname{tg} \alpha) \cos \alpha+t_{i}\left(\cos ^{2} \alpha \cdot \sin \varphi-\sin ^{2} \alpha \cdot \cos \varphi\right)} ; \\
q=\beta \sigma_{s} \frac{t_{i}\left(\cos ^{2} \alpha \cdot \sin \varphi-\sin ^{2} \alpha \cdot \cos \varphi\right)}{\varphi(b+x \cdot \operatorname{tg} \alpha) \cos \alpha+t_{i}\left(\cos ^{2} \alpha \cdot \sin \varphi-\sin ^{2} \alpha \cdot \cos \varphi\right)} .
\end{gathered}
$$

Тут $\alpha$-кут нахилу твірної профрілю до осі симетрії напівфабрикату; $y_{c p}$ - поточний радіус напівфабрикату; $R_{c p}$ - найбільший радіус ділянки деталі; $t_{i}$ - поточна товщина стінки деталі; $\mu$-коефіцієнт контактного тертя; $\beta$-коефіцієнт, що враховує вплив середнього головного напруження; $\sigma_{s}$ - границя текучості; $b$ - початкова ордината, яка дорівнює радіусу обичайки; $x$ - поточна довжина досліджуваної ділянки. 


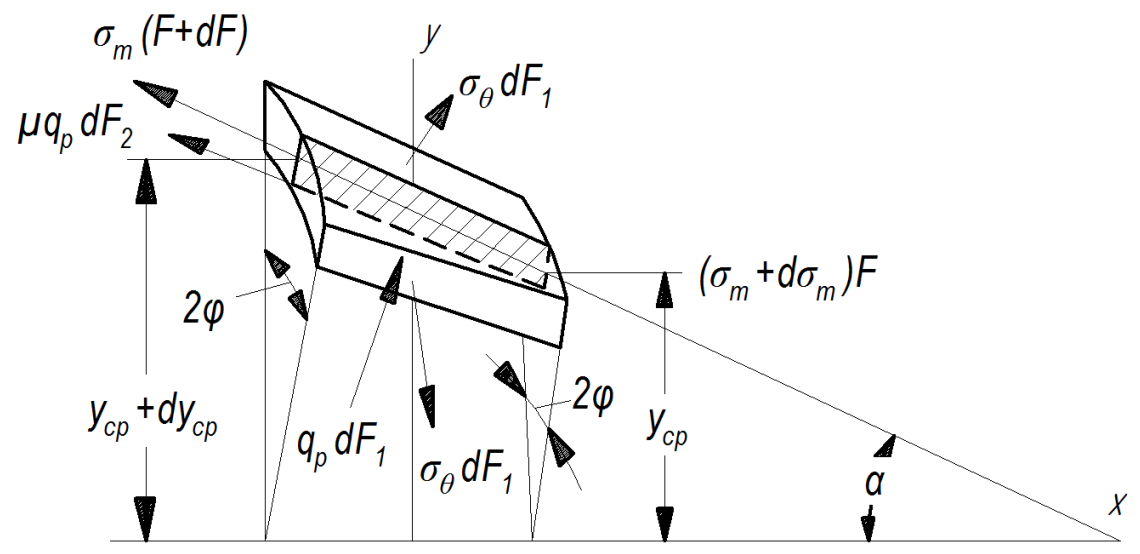

Рис. 4. Схема напруженого стану похилого елемента зони розтягнення

Відпрацьована послідовність розрахунку технологічного процесу за новою схемою, яка містить такі етапи:

- за конструкторською документацією визначається довжина і ширина плоскої заготовки;

- матеріал заготовок досліджується випробуваннями на розтягнення для виявлення умовних і дійсних характеристик та границі текучості;

- за відомим припустимим потоншенням $\left[\varepsilon_{r}\right]$ і границею текучості для даного матеріалу в його вихідному стані визначається найбільша припустима інтенсивність напружень;

- розраховуються величини деформацій і якщо розрахунки проводяться після профрілювання, то знімаються профілограми, які використовуються креслення деталі;

- визначається маршрут профілювання, призначаються радіуси заокруглень і коефіцієнти роздавання та обтискання для напівфабрикатів, будуються їх профрілі, визначається максимальне потоншення на заокруглених зразках;

- визначаються деформації і напруження та їх інтенсивності для крайових елементів і в небезпечних перерізах напівфабрикатів за переходами; для одних і тих самих елементів інтенсивності напружень повинні мають, але найбільша кінцева інтенсивність не може перевершувати припустиму;

- 3 урахуванням пружних деформацій заготовки будуються профрілі роликів і розраховуються колові швидкості;

- розраховується оптимальне зусилля за переходами, призначається подача та кількість обертів роликів.

3 урахуванням матеріалу $O_{c}$, який втрачається внаслідок оплавлення при зварюванні обичайок, і збільшення довжини заготовки $\Delta L_{3}$ в процесі завершального калібрування (розтягування) напівфрабрикату у штампі довжина плоскої заготовки

$$
L_{3}=\pi \cdot d_{c p} \cdot \rho_{1} \cdot+O_{c}-\Delta L_{3},
$$

де $d_{c p}$ - діаметр нейтральної поверхні профрілю деталі;

$\rho_{1}$ - поправковий коефіцієнт, який враховує величину відхилення серединної поверхні обичайки від нейтральної поверхні профрілю деталі, $\rho_{1}=0,98 \ldots 0,99$; 
$O_{c}=\Delta l_{0}+\Delta l_{o c} ; \quad \Delta L_{3}=(0,01 \ldots 0,03) L_{3} ; \quad \Delta l_{0}$ - припуск на оплавлення; $\Delta l_{o c}$ - припуск на осадження при зварюванні, $\Delta l_{0}=t_{3}+6, \Delta l_{o c}=\sqrt[3]{t_{3}}+0,9 t_{3}$.

Припуск під зварювання обичайок для типових деталей становить 14 мм (ободи 4,50E-16), 14 ... 15 мм (4J-13), 16 мм (5,50F-20), 18 мм (DW10-38, DW842), 17 .. 19 мм (W8-16, W7-20), 19 мм (DW11-38, W8-32), 19 .. 20 мм (DW 1238), $20 \ldots 21$ мм (DW14-30), 22 ... 23 мм (DW12-30), 25 мм (DW 20-26) і 28 мм (DW 18-24).

Розроблена схема дозволила знизити металомісткість деталей (табл. 2) і отримати суттєвий економічний ефект. При застосуванні цієї схемі усувається овальність виробів, виключається багаторазове повторне деформування одних і тих самих ділянок, зменшується зміцнення матеріалу.

Таблиця 2

Порівняльні показники металомісткості деталей

\begin{tabular}{|c|c|c|c|}
\hline \multirow{2}{*}{ Тип ободу } & \multicolumn{2}{|c|}{$\begin{array}{c}\text { Норма витрат матеріалу на одну } \\
\text { деталь, кг }\end{array}$} & $\begin{array}{c}\text { Економія } \\
\text { матеріалу на 1000 } \\
\text { виробів, кг }\end{array}$ \\
\cline { 2 - 3 } & $\begin{array}{c}\text { За традиційною } \\
\text { схемою }\end{array}$ & $\begin{array}{c}\text { За розробленою } \\
\text { схемою }\end{array}$ & 890 \\
\hline DW11-38 & 36,09 & 35,20 & 380 \\
\hline DW14-30 & 34,21 & 33,83 & 780 \\
\hline DW8-42 & 31,12 & 30,34 & 380 \\
\hline $5,50 \mathrm{~F}-20$ & 10,90 & 10,52 & 210 \\
\hline $4,50 \mathrm{E}-16$ & 6,50 & 6,29 & \\
\hline
\end{tabular}

\section{Висновки}

1. Миттєва контактна поверхня заготовки в осередку деформації не перевищує 2 \% від її бічної поверхні.

2. Потрібне зусилля у 5 - 10 разів менше, а трудомісткість у 2,2 - 3,4 раза менше, ніж у жорсткому секційному штампі.

3. Відносне зміцнення в найбільш напружених ділянках виробів становить $26 \ldots 29 \%$.

\section{Список літератури}

1. Потекушин, Н. В. Исследование процесса радиального профилирования / Н. В. Потекушин // Автомобильная промышленность. - 1976. - № 4 . - С. 33 - 36.

2. Використаний ресурс пластичності металу в процесі видавлювання внутрішньої метричної різі / В. А. Огородніков, О. В. Нахайчук, М. В. Любін, М. В. Бабак // Вісник ВПІ. - 1998. - № 1. - С. 68 - 72.

3. Матвійчук, В. А. Розробка маловідходних процесів фрормування тонкостінних циліндричних деталей / В. А. Матвійчук, В. М. Михалевич, В. О. Краєвський // Удосконалення процесів і обладнання обробки тиском в металургії і машинобудуванні (Донбаська державна машинобудівна академія). Краматорськ : ДДМА. - 2004. - С. 281-286.

4. Фролов, Є. А. Розрахунок основних параметрів радіально-ротаційного профрілювання металів при виготовленні колісних ободів різних типів і товщини / Е. А. Фролов, Б. О. Коробко, С. Г. Ясько // Відкриті інформаційні та комп'ютерні 
інтегровані технології : зб. наук. пр. Нац. аерокосм. ун-ту ім. М.Є. Жуковського „XAl”. - Харків. - 2020. - Вип. № 88. - С. $104-111$.

5. Романовский, В.П. Справочник по холодной штамповке / В. П. Романовский. - 6-е изд., перераб. и доп. - М. : Машиностроение, 1979. $520 \mathrm{c}$.

6. Мосьпан, Д. В. Применение морфологического анализа для подбора оборудования при формоизменении ободов колес / Д. В. Мосьпан, Р. Г. Пузырь, В. В. Драгобецький, Л. М. Драгобецкая, Ю. А. Бойко // Вісник КДПУ імені Михайла Остроградського. - Вип. 2/2008 (49). Ч. 2. Нові технології в машинобудуванні. - С. 101 - 103.

\section{References}

1. Potekushin N. V. Issledovanie protsessa radial'nogo profilirovaniya [Research of the radial profiling process] // Avtomobil'naya promyshlennost'. -1976. №4. - P. 33-36.

2. Vykorystanyi resurs plastychnosti metalu $v$ protsesi vydavliuvannia vnutrishnoi metrychnoi rizi [The resource of plasticity of metal in the process of extrusion of an internal metric cut is used] / V. A. Ohorodnikov, O. V. Nakhaichuk, M. V. Liubin, M. V. Babak // Visnyk VPI. - 1998. - № 1. - P. 68-72.

3. Matvijchuk V. A. Rozrobka malovidxodny`x procesiv formuvannya tonkostinny`x cy lindry`chny`x detalej [Development of low-flow processes for the formation of thin cylindrical parts] / V. A. Matvijchuk, V. M. My`xalevy`ch, V. O. Krayevs`ky`j // Udoskonalennya procesiv i obladnannya obrobky ty`skom $v$ metalurgiyi i mashy`nobuduvanni. - Kramators`k: DDMA. - 2004. - P. 281-286.

4. Frolov Ye. A. Rozraxunok osnovny'x parametriv radial'no-rotacijnogo profilyuvannya metaliv pry` vy gotovlenni kolisny`x obodiv rizny`x ty`piv i tovshhy 'ny [The selection of the main parameters of the radial-rotational metal profiling when preparing wheel rims of different types and products] / E. A. Frolov, B. O. Korobko, S. G. Yas`ko // Vidkry`ti informacijni ta komp'yuterni integrovani texnologiyi : zb. nauk. pr. Nacz. aerokosm. un-tu im. M.Ye. Zhukovs`kogo „XAl”. Xarkiv. - 2020. Vy`p. \# 88. - P. 104-111.

5. Romanovskij V. P. Spravochnik po holodnoj shtampovke [Cold forming reference] / V. P. Romanovskij. - 6-e izd., pererab. i dop. - Moskva : Mashinostroenie, 1979. $-520 \mathrm{p}$.

6. Mos'pan D. V. Primenenie morfologicheskogo analiza dlya podbora oborudovaniya pri formoizmenenii obod'ev koles [Application of morphological analysis for the selection of equipment for the shaping of wheel rims] / D. V. Mos'pan, R. G. Puzyr', V. V. Dragobeckij, L. M. Dragobeckaya, Yu. A. Bojko // Visny`k KDPU imeni My`xajla Ostrograds`kogo. - Vy`pusk 2/2008 (49). Chasty`na 2. "Novi texnologiyi v mashy`nobuduvanni» - P. 101-103

Надійшла до редакції 18.06.2021. Розглянуто на редколегії 20.06.2021.

\section{Reducing Metal Consumption of Rotationally Profiled Wheel Rims of Different Types and Thickness}

The research carried out made it possible to develop a new scheme for the process of rotary profiling of wheel rims, which allows to reduce the specific quantity of metal for parts. The essence of the solution lies in the fact that at the second step 
the jet central section is additionally made more powerful. This allows to change the nature of the deformation after the second step and to eliminate unnecessary thickening of the jet base. With an increase in the jet depth the edge sections are subjected to insignificant tensile stresses, while the stress-strain state of the part remains symmetric and constant at each point. The worked out sequence of calculating a new technological process allows calculating all technological parameters: width and length of a flat workpiece; maximum permissible stress in the workpiece material; a profiling route; as well as to identify deformations and stresses for edge elements and in hazardous areas. Further, taking into account the elastic deformations of the workpiece, the profile of the rollers was built, and then optimal deformation force along the transitions was calculated, then feed and the number of revolutions of the rollers were assigned. The new scheme made it possible to reduce metal consumption for parts and obtain a significant economic effect. Ovality of the part and multiple repeated deformation of the same sections of the workpiece are eliminated, and the degree of strengthening of the material is also reduced.

Key words: rotary processing, parameters, quality, rim, wheel, sheet.

\section{Відомості про авторів:}

Фролов Євгеній - доктор технічних наук, професор, кафедра будівельних машин і обладнання, Національний університет «Полтавська політехніка імені Юрія Кондратюка», м. Полтава, Україна; e-mail: itm.frolov@nupp.edu.ua; ORCID: 0000-0002-2691-5386.

Коробко Богдан - доктор технических наук, доцент, кафедра строительных машин и оборудования, Национальный университет «Полтавская политехника имени Юрия Кондратюка», г. Полтава, Украина; e-mail: korobko@nupp.edu.ua; ORCID: 0000-0002-9086-3904.

Ясько Станіслав - кандидат технічних наук, старший викладач, кафедра будівельних машин і обладнання, Національний університет «Полтавська політехніка імені Юрія Кондратюка», м. Полтава, Україна; e-mail: itm.yasko@nupp.edu.ua; ORCID: 0000-0001-6228-705X.

Агарков Віктор - кандидат технічних наук, заступник директора, начальник лабораторії, Державне підприємство "Харківстандартметрологія", м. Харків; e-mail:290@mti.kharkov.ua; ORCID 0000-0001-9883-0480

\section{About the Authors:}

Frolov Evgeniy - Doctor of Technical Sciences, Professor, Department of Construction Machinery and Equipment, National University "Yuri Kondratyuk Poltava Polytechnic», Poltava, Ukraine; e-mail: itm.frolov@nupp.edu.ua; ORCID:0000-0002-2691-5386.

Korobko Bogdan - Doctor of Technical Sciences, Associate Professor, Department of Construction Machinery and Equipment, National University «Yuri Kondratyuk Poltava Polytechnic», Poltava, Ukraine; e-mail: korobko@nupp.edu.ua; ORCID: 0000-0002-9086-3904.

Yasko Stanislav - Ph.D., Senior Lecturer, Department of Construction Machinery and Equipment, National University "Yuri Kondratyuk Poltava Polytechnic»,Poltava, Ukraine; e-mail: itm.yasko@nupp.edu.ua; ORCID:0000-00016228-705X.

Agarkov Victor - Candidate of Technical Sciences, Deputy Director, Head of Laboratory, State Enterprise "Kharkivstandartmetrologiya", Kharkiv; e-mail: 290@mti.kharkov.ua; ORCID 0000-0001-9883-0480 